Original Contribution

\title{
BIOMASS YIELD AND ANTIMICROBIAL SUBSTANCES PRODUCTION IN LIMITING - NUTRIENT CULTURES OF LACTOBACILLUS SPECIES
}

\author{
I. F. Fadahunsi*
}

Department of Microbiology, University of Ibadan, Ibadan, Nigeria

\begin{abstract}
Lactic acid bacteria had been reported to produce antimicrobial compounds such as lactic acid, hydrogen peroxide and diacetyl which are inhibitory to pathogenic bacteria.Attempt was therefore made in this study to screen for the antimicrobial property of these metabolites and to optimize their production based on growth nutrient formulation or by varying some components of the growth medium (De Mann Rogosa Sharpe i.e MRS) Four species of lactobacillus were isolated from fermented beverages such as ogi, kunnuzarki and pito and were identified as L. plantarum, L.delbruekii, L.reuteri and L. acidophilus.The result obtained from the screening of the antimicrobial compounds showed that some indicator organisms were inhibited while some were resistance to the metabolites of the LAB species. The nutrient limiting study revealed that varying glucose concentration significantly affected the biomass yield but did not show significant effect on the production of antimicrobial compounds.(p>0.05)However, the effect of varying peptone concentration revealed that there was significant effect on the antimicrobial compounds secreted while the biomass yield were insignificantly affected.At $1.0 \%$ concentration of peptone(control) a biomass of $20.00 \pm 0.14 \mathrm{mg} / \mathrm{ml}$ was recorded and the corresponding antimicrobial compounds produced were $19.00 \pm$ $0.16 \mathrm{~g} / \mathrm{l}$ of lactic acid , $0.360 \pm 0.14 \mathrm{~g} / \mathrm{l}$ of hydrogen peroxide and $1.90 \pm 0.26 \mathrm{~g} / \mathrm{l}$ of diacetyl, were recorded in L. Plantarum while at $0.5 \%$ concentration of peptone, a biomass of $19.68 \pm 0.43 \mathrm{mg} / \mathrm{l}$ was produced while the corresponding antimicrobial compounds were $25.00 \pm 0.48 \mathrm{~g} / 1$ of lactic acid, $0.54 \pm 0.17 \mathrm{~g} / \mathrm{lof}$ hydrogen peroxide and $2.80 \pm 0.71 \mathrm{~g} / \mathrm{l}$ of diacetyl However, at $0 \%$ concentration of peptone a biomass of 19.59 $\pm 0.39 \mathrm{mg} / 1$ was noted whilethe corresponding antimicrobial compounds were $17.00 \pm 0.74 \mathrm{~g} / 1$ of lactic acid, $0.33 \pm 0.12 \mathrm{~g} / 1$ of hydrogen peroxide and $1.70 \pm 0.22 \mathrm{~g} / \mathrm{l}$ of diacetyl .This trend was equally observed in all the species used. The limiting effect of tween-80 revealed that there was significant difference on both the biomass and antimicrobial substances produced. It could be concluded from this study that metabolites produced by LAB possess inhibitory properties and the production of these substances can be optimized by varying the concentration of some of the components constituting the growth medium.
\end{abstract}

Key words: Lactobacillus species,antimicrobial substances,biomass yield,nutrient-limiting.

\section{INTRODUCTION}

The antimicrobial properties of Lactic acid bacteria are of special interest in developing strong competitive starter cultures and utilization as biocontrol or biopreservative agent.

A subgroup of naturally occurring antimicrobial compounds are produced by lactic acid bacteria,(e.g Lactobacillus, Lactococcus, Pediococcusspecies) (1). They are used to inhibit spoilage microorganisms and, thus, prolong shelf life and preserve food quality. The antimicrobial

*Correspondence to: I.F Fadahunsi, Department of Microbiology, University of Ibadan, Ibadan, Nigeria, E-mail: sanmifadahunsi @yahoo.com effect of lactic acid bacteria has been appreciated by man for more than 100 years (2). These compounds produced by LAB exhibit broad spectrum antagonistic property to microorganisms (3). The characteristics aroma, flavor and sensory qualities of fermented food emanated from the action of the metabolites of lactic acid bacteria (4) used to ferment or produced them.

The higher the concentrations of the antimicrobial agent, the more rapid microorganisms are destroyed, though in some situations a lower concentration is sufficient to use. 
They are non-pathogenic bacteria that play a vital role in our everyday life from production of wholesome foods, vitamins and prevention of certain diseases due to their antimicrobial property(5). LAB grows under anaerobic conditions, (6) mesophylic in nature and can grow at temperature ranging from $5^{0} \mathrm{C}-45^{\circ} \mathrm{C}(7)$ These organisms are weakly proteolytic and lypolitic which are of interest to the food industry. The conventionally used phenotypic method in the identification of LAB (8) is gradually giving way to genetic techniques such as 16s rDNA sequencing which allows for a more consistent and accurate method of identification of individual strains (9) In addition to the organic acids (lactic acid, acetic acid), they also produced antimicrobial substances such as hydrogen peroxide, diacetyl and bacteriocins (10). Innovative approaches had been attempted as an alternative to antibiotic in the treatment of gastro-intestinal diseases and these include using livebio-therapeutic agents such bacterial isolates of LAB (11).

LAB competes with other microbes by modifying the microenvironment with their metabolic end products $(12,13)$. Consumption of LAB has some beneficial effects which include enhancing the immune system (14) improving health of the intestinal tract, synthesizing and enhancing bioavailability of nutrients, reducing symptoms of lactose intolerance (15) reducing risk of certain cancers and decreasing the prevalence of allergy in susceptible individuals
(16) This study was therefore carried out to screen for antimicrobial activities of lactic acid bacteria and investigate the effects of varying glucose, peptone and tween- 80 concentrations on the production of biomass and antimicrobial compounds in some selected species of Lactobacillus isolated from traditionally fermented African foods.

\section{MATERIALS AND METHODS Isolation procedure}

Isolation of lactobacillus spp.from fermented Kunni-zarki, pito and ogi was out carried by employing the serial dilution method of Meynell and Meynell (17) and using the pour plate method of Harrigan and McCane (18). The medium employed for isolation was de Mann Rogosa and Sharpe agar. The pHof the mediumwas adjusted to 5.5 and incubation was carried at $37^{\circ} \mathrm{C}$ anaerobically for $48 \mathrm{~h}$.

\section{Method of identification}

Identification of pure cultures of the isolates was carried out using the API $50 \mathrm{CH}$ strips and API50CH medium (API system MontalieuVercieu France).

\section{Screening for Antimicrobial activity}

The agar well diffusion method of Schillinger and Lucke (19) was employed. The plates were observed for zone of inhibitions which were indicated (+) where observed and negative (-) where not seen.

Table 1. Nutrient limiting formulation

\begin{tabular}{clll}
\hline $\begin{array}{l}\text { Number/ } \\
\text { code }\end{array}$ & $\begin{array}{l}\text { Glucose } \\
(\mathbf{g} / \mathbf{l})\end{array}$ & $\begin{array}{l}\text { Peptone } \\
(\mathbf{g} / \mathbf{l})\end{array}$ & $\begin{array}{l}\text { Tween-80 } \\
(\mathbf{m l} / \mathbf{l})\end{array}$ \\
\hline$* 1$ & 20 & 10 & 1 \\
2 & 10 & 10 & 1 \\
3 & 0 & 10 & 1 \\
4 & 20 & 5 & 1 \\
5 & 20 & 0 & 1 \\
6 & 20 & 10 & 05 \\
7 & 20 & 10 & 05 \\
\hline Control & & &
\end{tabular}

The nutrient limiting formulationis shown in Table 1. MRS broth (De mannRogosa and sharpe medium) was prepared by varying the concentrations of glucose,peptone and tween- 80 components of the medium (20). Each medium preparation was dissolved per liter of distilled 
water and $50 \mathrm{ml}$ aliquots was dispensed into $150 \mathrm{ml}$ Erlenmeyer flasks in four replicates and sterilized at $121^{\circ} \mathrm{C}$ for $15 \mathrm{mins}$. The flasks were separately inoculated with $0.1 \mathrm{ml}\left(5.0 \times 10^{4} \mathrm{cfu} / \mathrm{ml}\right)$ $24 \mathrm{~h}$ old culture of L.plantarum, L.reutei and L.delbrueckii and L. acidophilus and incubated anaerobically at $37^{\circ} \mathrm{C}$ for $48 \mathrm{~h}$.

\section{Biomass measurement}

Broth in each Erlenmeyer flask was centrifuged(Bechman J-MI model) and the supernatant was decanted into sterile McCartney bottles while the pellets were dried in an oven at $80^{\circ} \mathrm{C}$ for $24 \mathrm{~h}$. This was weighed to obtain the dry biomass, Un-inoculated flask served as control.

\section{Quantitative measurement of Antimicrobial compounds}

Lactic acid: Three drops of phenolphthaleinindicator were added to $25 \mathrm{ml}$ of each supernatant, in $150 \mathrm{ml}$ Erlenmeyer flask and titrated with $0.1 \mathrm{M}$ sodium hydroxide until a pink colour appeared. One $\mathrm{ml}$ of $0.1 \mathrm{M}$ sodium hydroxide solution is equivalent to $90.80 \mathrm{~g}$ of lactic acid (21).

Diacetyl: This was determined by transferring $25 \mathrm{ml}$ of supernatant into $150 \mathrm{mlErlenmeyer} \mathrm{flask}$ and $7.5 \mathrm{ml}$ of hydroxylamine solution was used for residual titration with $0.1 \mathrm{M}$ hydrochloric acid $(\mathrm{HCl})$ to a greenish yellow end point using bromophenol blue as an indicator The equivalent factor of hydrochloric acid to diacety is $21.5 \mathrm{mg}$ (21).

Hydrogen peroxide: Twenty $\mathrm{ml}$ of $0.1 \mathrm{M}$ dilute sulphuric acid was added to $25 \mathrm{ml}$ of the supernatant and was titrated against $0.1 \mathrm{M}$ potassium permanganate solution.A decolourization of the sample was regarded as the point. One $\mathrm{ml}$ of $0.1 \mathrm{M}$ potassium permanganate is equivalent to $1.7 \mathrm{mg}$ of hydrogen peroxide (21).

\section{RESULTS}

Four species of lactobacillus were isolated from ogi, pito and kunni-zarki. Their identities were confirmed as L. plantarum, L. delbrueckii, $L$. acidophilus and L. reuteri.

Table 2 shows Susceptibility of indicator organisms to antimicrobial substance produced by LAB Spp. the antagonistic pattern of the metabolites produced by the LAB species against selected bacterial pathogens while Table 3 shows the effect of varying glucoseconcentrations on biomass yield and antimicrobial compounds production by Lactic acid bacteria.

Table 4 shows the effect of limiting peptone concentration on biomass yield and antimicrobialproduction by Lactic acid bacteria.

Table 5 shows the effect of varying tween- 80 concentration on biomass yield and antimicrobial compounds production by Lactic acid bacteria.

Table 2. Susceptibility of indicator organisms to antimicrobial compounds produced by LAB Spp

\begin{tabular}{|c|c|c|c|c|c|c|c|c|c|}
\hline & $\begin{array}{l}\text { S. } \\
\text { awreus }\end{array}$ & $\begin{array}{l}E . \\
\text { coli }\end{array}$ & $\begin{array}{l}\text { S. } \\
\text { sonnei }\end{array}$ & $\begin{array}{l}\text { S. } \\
\text { flexari }\end{array}$ & $\begin{array}{l}\text { S. } \\
\text { dysentariae }\end{array}$ & $\begin{array}{l}\text { S. } \\
\text { enteridis }\end{array}$ & $\begin{array}{l}\text { S. } \\
\text { typhü }\end{array}$ & $\begin{array}{l}\text { S.typhi } \\
\text { murium }\end{array}$ & $\begin{array}{l}\text { V. } \\
\text { cholerae }\end{array}$ \\
\hline L. planterum & - & + & + & $H$ & ++ & - & - & + & + \\
\hline L. delbruedai & - & ++ & + & + & ++ & - & - & + & + \\
\hline L. acidophilus & + & + & + & - & - & + & - & - & ++ \\
\hline L. reuteri & + & ++ & + & - & + & + & - & + & - \\
\hline
\end{tabular}

The antimicrobial screening procedures showed that they produced antimicrobial compounds such lactic acid hydrogen peroxide and diacetyl which inhibited some of the indicator microorganisms tested but did not inhibit some. Metabolites obtained from $L$. plantarum and $L$. delbrueckii inhibited E. coli, S. sonnei, $S$. flexneri, S. dysenteriae, S. typhimurium, and $V$. cholera but did not inhibit $S$. aureus, andS. typhi, while L. acidophilus inhibited, S. aureus, E. coli, $S$. sonneiS. enteritidis and $V$. choleriaebut did not show inhibition to $S$. flexneri, $S$. dysenteriae, $S$. typhi, S. typhimurium. Inhibition zones were seen around $S$. aureus,E. coli, $S$. sonnei $S$. dysenteriae $S$. enteritidis and $S$. typhimurium while there was no inhibition zone around $S$. flexneri, $S$. typhii, and $V$. choleraewhen the metabolites from L.reuteriwas tested (Table2). 
Table 3. Effect of limiting glucose concentration on biomass yield and antimicrobial compounds production by Lactic acid bacteria

\begin{tabular}{|c|c|c|c|c|c|}
\hline \multicolumn{2}{|l|}{ Antimicrobial/Biomass } & \multirow{2}{*}{$\begin{array}{l}\text { L. plantarum } \\
19.00 \pm 0.16 a\end{array}$} & \multirow{2}{*}{$\begin{array}{l}\text { L. reuteri } \\
14.00 \pm 0.30 \mathrm{a}\end{array}$} & \multirow{2}{*}{$\begin{array}{l}\text { L. acidophilus } \\
19.00 \pm 0.44 a\end{array}$} & \multirow{2}{*}{$\begin{array}{l}\text { L. delbrueckii } \\
15.00 \pm 0.36 a\end{array}$} \\
\hline Lactic & G1 & & & & \\
\hline Acid $(g / 1)$ & $\mathrm{G} 2$ & $18.80 \pm 0.16 a$ & $13.70 \pm 0.14 a$ & $18.70 \pm 0.36 a$ & $14.60 \pm 0.39 a$ \\
\hline & G3 & $18.50 \pm 0.56 a$ & $13.60 \pm 0.06 a$ & $18.50 \pm 0.30 \mathrm{a}$ & $14.50 \pm 0.08 a$ \\
\hline \multirow[t]{3}{*}{ Hydrogenperoxide $(g / 1)$} & G1 & $0.360 \pm 0.14 a$ & $0.280 \pm 0.10 \mathrm{a}$ & $0.310 \pm 0.14 a$ & $0.262 \pm 0.02 a$ \\
\hline & G2 & $0.358 \pm 0.07 a$ & $0.278+0.13 a$ & $0.307 \pm 0.29 a$ & $0.261 \pm 0.06 a$ \\
\hline & G3 & $0.365 \pm 0.11 \mathrm{a}$ & $0.275 \pm 0.04 a$ & $0.306 \pm 0.07 a$ & $0.260 \pm 0.11 \mathrm{a}$ \\
\hline \multirow[t]{3}{*}{ Diacetyl $(\mathrm{g} / \mathrm{l})$} & G1 & $1.90 \pm 0.26 a$ & $1.40 \pm 0.39 a$ & $1.60 \pm 0.04 a$ & $1.30 \pm 0.08 a$ \\
\hline & G2 & $1.86 \pm 0.11 a$ & $1.36 \pm 0.0 .8 \mathrm{a}$ & $1.59 \pm 0.20 \mathrm{a}$ & $1.30 \pm 0.02 \mathrm{a}$ \\
\hline & G3 & $1.85+0.22 \mathrm{a}$ & $1.35 \pm 0.08 a$ & $1.55 \pm 0.10 a$ & $1.25 \pm 0.00 \mathrm{a}$ \\
\hline \multirow{3}{*}{$\begin{array}{c}\text { Biomass } \\
(\mathrm{mg} / \mathrm{l})\end{array}$} & G1 & $20.00 \pm 14 a$ & $12.00 \pm 13 a$ & $19.00 \pm 16 a$ & $13.00 \pm 0.07 a$ \\
\hline & G2 & $17.00 \pm 0.11 b$ & $9.00 \pm 0.28 b$ & $17.00 \pm 0.716$ & $10.00 \pm 0.11 b$ \\
\hline & G3 & $7.05+0.47 c$ & $5.00 \pm 0.07 c$ & $8.00+0.36 c$ & $4.00 \pm 0.01 c$ \\
\hline
\end{tabular}

Means followed by the same letter(s) are not significant different ( $\mathrm{p}>0.05)$ Duncan's multiple range tests. Each value represent mean of three replicates.

Table 4. Effect of limiting peptone concentration on biomass yield and antimicrobial production by Lactic acid bacteria

\begin{tabular}{llllll}
\hline Antimicrobial/Biomass & & L. plantarum & L. reuteri & L. acidophilus & L. delbrueckü \\
\hline Lactic & P1 & $19.00 \pm 0.44 \mathrm{c}$ & $14.00 \pm 0.30 \mathrm{c}$ & $19.00 \pm 0.44 \mathrm{a}$ & $15.00 \pm 0.36 \mathrm{c}$ \\
Acid $(\mathrm{g} / \mathrm{l})$ & P2 & $25.00 \pm 0.48 \mathrm{c}$ & $25.00 \pm 0.48 \mathrm{c}$ & $18.70 \pm 0.36 \mathrm{a}$ & $23.60 \pm 0.65 \mathrm{a}$ \\
& P3 & $22.00 \pm 0.74 \mathrm{~b}$ & $22.00 \pm 0.74 \mathrm{~b}$ & $18.50 \pm 0.30 \mathrm{a}$ & $20.00 \pm 0.47 \mathrm{~b}$ \\
Hydrogenperoxide $(\mathrm{g} / \mathrm{l})$ & P1 & $0.36 \pm 0.014 \mathrm{c}$ & $0.36 \pm 0.014 \mathrm{c}$ & $0.310 \pm 0.14 \mathrm{a}$ & $0.31 \pm 0.56 \mathrm{c}$ \\
& P2 & $0.54 \pm 0.17 \mathrm{a}$ & $0.54 \pm 0.17 \mathrm{a}$ & $0.307 \pm 0.29 \mathrm{a}$ & $0.55 \pm 0.24 \mathrm{a}$ \\
& P3 & $0.50 \pm 0.12 \mathrm{~b}$ & $0.50 \pm 0.12 \mathrm{~b}$ & $0.306 \pm 0.07 \mathrm{a}$ & $0.40 \pm 0.05 \mathrm{~b}$ \\
Diacetyl$(\mathrm{g} / \mathrm{l})$ & P1 & $1.90 \pm 0.26 \mathrm{c}$ & $1.90 \pm 0.26 \mathrm{c}$ & $1.60 \pm 0.04 \mathrm{a}$ & $1.30 \pm 0.08 \mathrm{c}$ \\
& P2 & $2.80 \pm 0.71 \mathrm{a}$ & $2.80 \pm 0.71 \mathrm{a}$ & $1.59 \pm 0.20 \mathrm{a}$ & $2.10 \pm 0.9 \mathrm{a}$ \\
& P3 & $2.60 \pm 0.22 \mathrm{~b}$ & $2.60 \pm 0.22 \mathrm{~b}$ & $1.55 \pm 0.10 \mathrm{a}$ & $1.50 \pm 0.7 \mathrm{~b}$ \\
Biomass & P1 & $20.0 \pm 0.11 \mathrm{a}$ & $12.00 \pm 0.13 \mathrm{a}$ & $19.00 \pm 16 \mathrm{a}$ & $13.00 \pm 0.07 \mathrm{a}$ \\
$(\mathrm{mg} / \mathrm{l})$ & P2 & $19.68 \pm 0.43 \mathrm{a}$ & $19.68 \pm 0.43 \mathrm{a}$ & $17.00 \pm 0.71 \mathrm{~b}$ & $12.60 \pm 0.28 \mathrm{a}$ \\
& P3 & $19.59 \pm 0.39 \mathrm{a}$ & $19.59 \pm 0.39 \mathrm{a}$ & $8.00 \pm 0.36 \mathrm{c}$ & $12.55 \pm 0.39 \mathrm{a}$ \\
\hline
\end{tabular}

Means followed by the same letter(s) are not significant different ( $p>0.05)$ Duncan's multiple range tests. Each value represent mean of three replicates.

Table 5.The Effect of Limiting Tween-80 concentration on biomass yield and antimicrobial compounds production by Lactic acid bacteria

\begin{tabular}{llllll} 
AntimicrobialBiomass & & L. phntarwn & L. re uteri & L. acidophilus & L. delbrueckii \\
\hline Lactic & T1 & $19.00 \pm 0.16 \mathrm{a}$ & $14.00 \pm 0.30 \mathrm{a}$ & $19.00 \pm 0.44 \mathrm{a}$ & $15.00 \pm 0.36 \mathrm{a}$ \\
Acid (g/1) & T2 & $16.70 \pm 0.71 \mathrm{a}$ & $11.00 \pm 0.51 \mathrm{~b}$ & $16.00 \pm 0.51 \mathrm{a}$ & $12.00 \pm 0.30 \mathrm{a}$ \\
& T3 & $12.00 \pm 0.11 \mathrm{c}$ & $7.00 \pm 0.38 \mathrm{c}$ & $13.15 \pm 0.05 \mathrm{c}$ & $11.00 \pm 0.72 \mathrm{c}$ \\
Hydrogenperoxide (g1) & T1 & $0.310 \pm 0.14 \mathrm{a}$ & $0.28 \pm 0.1 \mathrm{a}$ & $0.310 \pm 0.14 \mathrm{a}$ & $0.20 \pm 0.02 \mathrm{a}$ \\
& T2 & $0.39 \pm 0.04 \mathrm{a}$ & $0.15 \pm 0.21 \mathrm{~b}$ & $0.24 \pm 0.17 \mathrm{~b}$ & $0.20 \pm 0.10 \mathrm{~b}$ \\
& T3 & $0.23 \pm 0.11 \mathrm{c}$ & $0.12 \pm 0.01 \mathrm{c}$ & $0.15 \pm 0.05 \mathrm{c}$ & $0.14 \pm 0.01 \mathrm{c}$ \\
Diacetyl(g/1) & T1 & $1.60 \pm 0.26 \mathrm{a}$ & $1.40 \pm 0.31 \mathrm{a}$ & $1.60 \pm 0.04 \mathrm{a}$ & $1.3 \pm 0.80 \mathrm{a}$ \\
& T2 & $1.60 \pm 0.04 \mathrm{a}$ & $1.30 \pm 0.25 \mathrm{~b}$ & $1.30 \pm 0.12 \mathrm{~b}$ & $1.2 \pm 0.80 \mathrm{~b}$ \\
Biomass & T3 & $1.40 \pm 0.25 \mathrm{c}$ & $1.00 \pm 0.63 \mathrm{c}$ & $1.10 \pm 0.63 \mathrm{c}$ & $1.00 \pm 0.6 \mathrm{c}$ \\
(mg:1) & T1 & $20.00 \pm 0.14 \mathrm{a}$ & $12.00 \pm 17 \mathrm{a}$ & $19.00 \pm 16 \mathrm{a}$ & $13.00 \pm 0.07 \mathrm{a}$ \\
& T2 & $17.00 \pm 0.44 \mathrm{~b}$ & $9.00 \pm 0.61 \mathrm{a}$ & $15.00 \pm 0.28 \mathrm{~b}$ & $11.00 \pm 0.14 \mathrm{~b}$
\end{tabular}


Means followed by the same letter(s) are not significant different ( $p>0.05)$ Duncan's multiple range tests. Each value represent mean of three replicates.

It was observed that at $2 \%$ glucose concentration (control G1) the biomass yield recorded was $20.00 \pm 0.14 \mathrm{mg} / 1$ which decreased significantly (P> 0.05 ) to $17.00 \pm 0.11 \mathrm{mg} / \mathrm{l}$ at $1 \%$ glucose concentration $(\mathrm{G} 2)$ and finally decreased significantly to $7.05 \pm 0.74 \mathrm{mg} / 1$ at $0 \%$ conc. (G3). The antimicrobial compounds production showed that at $2 \%$ glucose concentration (control G1) the lactic acid produced decreased insignificantly from $19.00 \pm 0.16 \mathrm{~g} / 1$ to $18.80 \pm 0.0 .16 \mathrm{~g} / 1$ at $1 \%$ glucose conc. $(\mathrm{G} 2)$ and decreased insignificantly to $18.50 \pm 0.56 \mathrm{~g} / 1$ at $0 \%$ (G3). The hydrogen peroxide recorded at $2 \%$ glucose concentration (control G1) was $0.36 \pm 0.14 \mathrm{~g} / 1$ which decreased insignificantly to $0.358 \pm 0.07 \mathrm{~g} / 1$ at $1 \%$ glucose conc. $(\mathrm{G} 2)$ and further decreased to $0.3568 \pm 0.11 \mathrm{~g} / 1$ at $0 \%$ conc. (G3), while the diacetyl produced at $2 \%$ conc. glucose (control G1) decreased insignificantly from $1.90 \pm 0.26 \mathrm{~g} / 1$ to $0.186 \pm 0.11 \mathrm{~g} / 1$ at $1 \%$ conc.(G2) and further decreased to $1.85 \pm 0.22 \mathrm{~g} / 1$ at $0 \%$ conc.(G3) The same trend was observed in all the tested Lactic acid bacteria (Table 3).

The result of varying peptone concentration on biomass yield and antimicrobial compounds production in $L$. plantarum is shown in Table 4.The biomass yield recorded at $1 \%$ peptone conc (P1control) was $20.00 \pm 0.11 \mathrm{mg} / 1$ which decreased insignificantly to $19.68 \pm 0.43 \mathrm{mg} / 1$ at $0.5 \%$ peptone conc. (P2) and further decreased to $19.59 \pm 0.39 \mathrm{mg} / \mathrm{ml}$ at $0 \%$ peptone conc. (P3) The lactic acid produced at $1 \%$ peptone conc. (control P1) was $19.00 \pm 0.44 \mathrm{~g} / 1$ which increased significantly to $25.00 \pm 0.48 \mathrm{~g} / 1$ at $0.5 \%$ peptone conc. (P2) and decreased significantly to $17.00 \pm 0.07 \mathrm{~g} / 1$ at $0 \%$ conc.(P3)while the hydrogen peroxide produced at $1 \%$ peptone conc.(P1control) increased significantly from $0.36 \pm 0.14 \mathrm{~g} / 1$ to $0.54 \pm 0.17 \mathrm{~g} / 1$ at $0.5 \%$ peptone conc.(P2) which decreased significantly to $0.33 \pm 0.12 \mathrm{~g} / 1$ at $0 \%$ peptone conc.(P3). However, the quantity of diacetyl produced at $1 \%$ peptone conc. (control P1) was $1.90 \pm 0.26 \mathrm{mg} / 1$ which increased significantly to $2.80 \pm 0.71 \mathrm{~g} / 1$ at $0.5 \%$ peptone conc. $(\mathrm{P} 2)$ and decreased significantly to $1.70 \pm 0.22 \mathrm{~g} / 1$ at $0 \%$ peptone conc.(P3)The same trend was observed in all the tested Lactic acid bacteria.

Table 5 shows the result of the effect of varying tween- 80 concentration on biomass yield and antimicrobial compounds production in $L$. plantarum.At $1 \mathrm{ml}$ conc. of tween-80 (control T1) the biomass recorded was $20.00 \pm 0.11 \mathrm{mg} / 1$ which decreased significantly to $17.00 \pm 0.44 \mathrm{mg} / 1$ at $0.5 \mathrm{ml}$ conc. (T2) which further decreased to $14.00 \pm 0.06 \mathrm{mg} / 1$ at $0 \%$ conc. of tween- 80 (T3)The lactic acid produced at $1.0 \mathrm{ml}$ conc. of tween-80 (control T1) was $19.00 \pm 0.16 \mathrm{~g} / 1$ which decreased to $16.00 \pm 0.71 \mathrm{~g} / 1$ at 0.5 mltween- 80 conc. (T2) and further decreased significantly to $12.00 \pm 0.11 \mathrm{~g} / 1$ at $0 \%$ conc. of tween-80 (T3) while the hydrogen peroxide recorded at $1.0 \mathrm{ml}$ conc. of tween-80 conc. (controlT1) was $0.36 \pm 0.14 \mathrm{mg} / 1$, which decreased to $0.29 \pm 0.04 \mathrm{mg} / 1$ at $0.5 \mathrm{ml}$ conc. of tween-80(T2), and further decreased significantly to $0.23 \pm 0.11 \mathrm{~g} / 1$ at $0 \mathrm{ml}$ conc. of tween-80(T3). The diacetyl monitoring showed that $1.90 \pm 0.26 \mathrm{~g} / 1$ was produced at $1 \mathrm{ml}$ conc. of tween- 80 (control T1) which decreased significantly to $1.600 .22 \mathrm{~g} / 1$ at $0.5 \mathrm{ml}$ conc. (T2) and further decreased to $1.40 \pm 0.25 \mathrm{~g} / 1$ at $0 \mathrm{ml}$ conc. (T3)The same trend was observed in all the tested Lactic acid bacteria.

\section{DISCUSSION}

Four species of Lactobaccillus were isolated from ogi, kuunu-zarki and pito and they were identified as $L$. plantarum, $L$. reuter, $L$. acidophilus and $L$. delbrucekii. This finding corroborates the earlier submission of Okereke and Montiville (22) which indicated that Lactobacillus species are predominantly wide spread in nature including African fermented food. Species of Lactobacillus are capable of inhibiting other microorganisms by their abilities to produce antimicrobial compounds (23). Several workers have reported the antimicrobial activities of LAB filtrates towards gram positive indicators $(24,25,26,27)$. In addition lactic acid produced by LAB lowers the $\mathrm{pH}$ in their growth environment and this property convers the ability to antagonize other bacteria (28). It is reported by Dike and Sanni (29) that the undissociated form of lactic acid penetrates the cell membrane thereby protonating the cell cytoplasm with hydrogen ions and this mediates the antimicrobial effect of disintegrating gradient resulting in bacteriocidal activity of lactic acid on targeted bacteria. Diacetyl is a compound produced by $\mathrm{LAB}$ which is responsible for flavouring in fermented foods and is antimicrobial in nature (30). This compound acts in synergy with organic acids and hydrogen peroxide to enhance antimicrobial property (31).The of ability of LAB to produce antimicrobial compounds e.g hydrogen peroxide 
is due to the absence of catalase in these microorganisms that causes the accumulation of hydrogen peroxide $\left(\mathrm{H}_{2} \mathrm{O}_{2}\right)$ which inhibits bacteria and fungi (32). The antimicrobial effect of hydrogen peroxide can be linked to its oxidizing effect on the cell membrane of the pathogens that come in contact with it and destruction of the cellular protein (28). During fermentation, the carbon dioxide produced creates an anaerobic micro environment which is toxic to aerobic bacteria, and lactic acid is also produced that contributes to a decrease in $\mathrm{pH}$ $(33,11,34)$. The nutrient limiting study revealed that the variation of glucose concentration showed a significant increase on the production of biomass because as glucose concentration is increased, the biomass increased correspondingly. This observation might be due to the ability of LAB species to rapidly utilize glucose because they possess a relatively efficient phosphenol pyruvate dependent phosphotransferase system for glucose transport and metabolism which resulted in the production of biomass (35). In addition glucose is considered the main carbon source by all microorganisms due to its size, fast uptake, metabolism and cellular energy conversion. Cang (36) also reported that low glucose concentration repressed formation of antibiotic like substances when included in their growth medium. The variation of peptone showed an insignificant effect on the production of biomass but a significant effect on the production of antimicrobial compounds.It was observed that peptone at $1 \%$ concentrationstimulated the production of small quantities of antimicrobial substances, but at $0.5 \%$ peptone concentration, the highest concentration of antimicrobial substances was recorded. This occurrence might have emanated from the resultant stress the organisms were exposed to by limiting its peptone requirement. Tween- 80 variation had effect on both biomass yield and antimicrobial substances produced. As tween -80 concentration was increased, the biomass yield and the antimicrobial substances produced increased correspondingly. This occurrence might be caused by the surfactant nature of Tween-80, which increases the permeability of the cell membrane and this could accelerate diffusion of nutrient into the cell leading (37) to an increased uptake of nutrient by the LAB species with concomitant increase in biomass yield and production of antimicrobial compounds.

\section{CONCLUSION}

It could then be concluded that for the optimization of biomass production, and antimicrobial compounds, there is need to note that the composition of MRS (de Mann Rogosa and Sharpe) mediumshould consist of $20 \mathrm{~g}$ of glucose, $5 \mathrm{~g}$ of peptone and $1 \mathrm{ml}$ of tween- 80 in $1000 \mathrm{ml}$ of distilled water in the presence of other componentsin the standard specified quantities The need to optimize production of biomass and antimicrobial substances of Lactobacillus species arise from the fact that they are food grade microorganisms with antimicrobial activities which inhibits many Gram-positive bacteria associated with food spoilage and food borne illness $(24,38)$ and retain this property after heat treatment in foods $(39,40)$ They are nontoxic and nonpathogenic to animals and thus they are used to enhance safety and shelf life of many foods $(41,33)$

\section{ACKNOWLEDGEMENTS}

I want to use this opportunityto thank the Department of Microbiology, University of Ibadan Nigeria, for allowing me to make use of the facilities in the Food and Industrial laboratory for the execution of this research work.

\section{REFERENCES}

1. Davidson, P.M and Harrison, M.A.,Resistance and Adaptation to FoodAntimicrobials, Sanitizers, and Other Process Controls.Scientific Status Summary, Food Technology56. 11:69-78. 2002.

2. Savadogo, A.,A.,T,Ouattara C.,W.,Savadogo,P, N., Ouattara, S.,Aboubacar,S. and.Traore, A.,Micoorganisms involved in Fulani fermentation milk in Burkina Faso, Oak. J. Nutr., 3: 134-139.2004.

3. Leroy, F. and De Vuyst, L. Lactic acid bacteria as functional starter cultures for the food fermentation industry.Trend in Food Science and Technology15:67-78.2004.

4. FAO/WHO/OIE, Expert Consultation on antimicrobial use in aquaculture and antimicrobial resistance, Seoul, Republic of South Korea, 13-16 June.FishCulturist.36,191.Fishing newsbook Ltd. pp.480-483,2006.

5. Afolabi, R.O., Bankole, O.M and Olaitan, J.O.Production and characterization of antimicrobial agents by lactic acid bacteria isolated from fermented foods. The International Journal of Microbiology.4:2-6, 2008. 
6. Khalid,K., An Overview of Lactic acid bacteria. International Journal of Biosciences 1:3:1-13,2011.

7. Wood, B.J.B. and Holzapel, W.H., The General of Lactic acid bacteria. Vol 2 Blackie Academic and Professional.Glasgow, 1995.

8. Corsetti, A., Lavvermicocca, P., Morea, M., Baruzzi, F., Tosti, N. and Gobbetti, M.,Phenotypic and molecular identification and clustering of lactic acid bacteria and yeast from wheat (species Triticum durum and Triticumaestitvum) sourdoughs of Southern Italy. International Journal of Food Microbiology64:1-2:95-104, 2001.

9. Buddhiman, T., Jyoti, P.T., Ulrich, S., Charles, M.A.P.F., Micheal, G. and Wilhelm, H.H.,Phenotypic and genotypic identification of lactic acid bacteria isolated from ethnic fermented bamboo tender shoots of North East India. International Journal of Food Microbiology 121:1:35-40,2008.

10.Rattanachaikunsopon, P. and Phumkhachorn, P., Lactic acid bacteria: their antimicrobial compounds and their uses in food production. Annuals of Biological Research1:4:218228.2010 .

11.Oyetayo, V.O., Adetunji,F.C. and Akinyosoya,F.A.,Safety and protective effect of Lactobacillus acidophilus and Lactobacillus casei used as probiotic agent in vivo. Afr. J. Biotechn., 2: 448- 452, 2003.

12.Niku-Paavola, M.L., Laitila, A., MattilaSandholm, T. and Haikara, A.,New types of antimicrobial compounds produced by Lactobacillus plantarum. Journal of Applied Microbiology 86:29-35,1999.

13.Savadogo, A., OuattaraCheik, A.T., BassoleImael, H.N., Traore, S.A.,Bacteriocins and lactic acid bacteria. African Journal of Biotechnology5:9: 678683, 2006.

14.Chang, B.L., Sheik, Y.H., Wang, L.H., Liao, C.K. and Gill, H.S.Enhancing Immunity by Dietary Consumption of a Probiotic Lactic Acid Bacterium (Bifidobacteriumlactis HN019): Optimization and Definition of Cellular Immune Responses. EuropeanJournalofClinical Nutrition54:849855, 2000.

15.Marteau, P., de Vrese, M., Cellier, C.J.and Schrezenmeir, J.Protection from Gastrointestinal Diseases with the Use of Probiotics.AmericanJournalofClinical Nutrition.73: 430-436, 2001.
16.Saikali, J., Picard, C. and Freitas, M., Fermented milks, probiotic cultures and colon cancer. Nutrition Cancer 49:1:14-24, 2004.

17. Meynell, G. O. and Meynell, E.,Theory and Practical in Experimental Bacteriology. Microbiology and Biotechnology 39: 166173,1970 .

18.Harrigan, W.F. and McCance, M.E., laboratory methods in microbiology.Academic press, London, UK,pp 1-362,1966.

19. Schillinger, U. and F.K. Lucke, Antibacterial activity of lactobacillus sake isolated from meat. Appl.Environ. Microbiol., 55: 1901-1906, 1989.

20.Ruiz- Barba, J.L. and Jimenez-Diaz,R., Vitamins and amino acids requirements of L. plantarum isolated from green olive fermentation. J.AppBacteriol., 76: 350-55, 1994.

21.A.O.A.C. Methods of the Association of official Analytical chemist, Benjamin Franklin station, Washington, D.C.2000.

22.Okereke, A. and Montiville, T.J.,Bacteriocin Inhibition of Clostridium botulinum spores by lactic Acid bacteria J. Food Protec., 54: 349353,1991 .

23.Okereke, H. C., Achi, O. K., Ekwenye, U. N. and Orji, F. A.,Antimicrobial properties of probiotic bacteria from various sources. African Journal of Biotechnology11:39:94169421, 2012.

24.De Vuyst L, Foulquié MR, Revets $H$. Screening for enterocins and detection of hemolysin and vancomycin resistance in Enterococciof different origins. Int. J. Food Microbiol., 84: 299-318. 2003.

25.Mareková M, Lauková A, De Vuyst L, Skaugen M, Nes I. F. Partial characterization of bacteriocins produced by environmental strain Enterococcus faecium EK13. J. Appl. Microbiol., 94: 523-530. 2003.

26. Strompfová V, Laukova A. In vitro study on bacteriocin production of Enterococci associated with chickens. Anaerobe, 13: 228237. 2007.

27.Pinto AL, Fernandes M, Pinto C, Albano H, Castilho F, Teixeira P,Gibbs PA. Characterization of anti-Listeria bacteriocins isolated from shellfish: Potential antimicrobials to control nonfermented seafood. Int. J. Food Microbiol., 129: 50-58. 2009.

28..Magnusson J. Antifungal LAB, Phd Thesis Swedish University of Agricultural Sciences. 2003. 
29.Dike K. S. and Sanni A. I. Influence of starter culture of LAB on the shelf life of Agidi an indegineous fermented cereal product. African Journal of Biotechnology, 9 (46): 7922- 7927. 2010.

30.Earnshaw R. G. The antimicrobial action of LAB. Natural food preservation system. LAB in health and disease, 211- 232. 1992.

31.Asma Saleh W. El- Mabrok, Zaiton H., Ahmed M. M., Khaled M. A. Antifungal activity of Lactobacillus plantarum LAB- C5 and LAB- G7 isolated from Malaysian fruit. Acta Biological Malaysiana 2(1): 22- 33. 2013.

32.Caplice, E. and Fitzgerald, G.F., Food fermentation: role of microorganisms in food production and preservation. International Journal of Food Microbiology50:131-149, 1999.

33.Cleveland, J., Montville, T.J., Nes, I.F., and Chikindas, M.L.,Bacteriocins: safe, natural antimicrobials for food preservation. International Journal of Food microbiology.71:1-20, 2001.

34.Savadogo, A., OuattaraCheik, A.T., BassoleImael, H.N. and Traore, S.A., Antimicrobial Activities of Lactic Acid Bacteria Strains Isolated from Burkina Faso Fermented Milk. Pakistan Journal of Nutrition3:3: 174-179, 2004.

35.Thompson, J., Lactic acid bacteria model systems for in vitro studies of sugar transport and Metabolism in Gram-positive organisms Biochemie, 70: 325-336, 1988.

36. Cang S. High production of prodigiosin in Serratia marcesens grown on ethanol. Biotech. Lett. 22: 1761-1765 .2000.

37.Vignolo, G.M., Kairuz,M.N.,Jalgo,A.P., and Olive,G., Influence of growth conductions on the production of Iactocin 705, a bacteriocin produced byLactobacilluscasei CRL 5 . J.Appl. Bacteriol., 78: 5-10, 1994.

38.Adeniyi, B. and Iveren, D.,Antifungal capacity of Lactic acid bacteria isolated from salad vegetables. African Journal of Biomedical Research14:137 -141, 2011.

39.Daeschel, M.A., Antimicrobial substances from lactic acid bacteriafor use as food preservatives. Food Technology1:164-167, 1989.

40.Muhialdin, B.J., Hassan, Z., Sadon, S., Zulkifli, N.A. and Azfar, A.A., Effect PHofand heat treatment on antifungal activity of Lactobacillus fermentum, Lactobacillus pentosus and Pediococcuspentosaceus.Innovative Romanian Food Biotechnology 8:41-53,2011. 41.Bhunia, A.K., Johnson, M.C. and Ray, B, Purification, characterization and antimicrobial Spectrum of a bacteriocin produced by pediococcusacidilactic J. Appl. Bacteriol., 65: 261-268, 1988. 